\title{
Lipoma of the corpus callosum
}

\author{
Muna AlJallaf, ${ }^{1}$ Salwa AlJanahi, ${ }^{2}$ Tarik AlJanabi $^{3}$
}

${ }^{1}$ Emergency Medicine Department, Dubai Health Authority, United Arab Emirates

${ }^{2}$ Emergency Medicine Department, Dubai Health Authority, United Arab Emirates

${ }^{3}$ Emergency Medicine Department, Ministry of Presidential Affairs, Um AlQuwain, United Arab Emirates

Correspondence to Dr Muna AlJallaf,

muna_aljallaf@hotmail.com

Accepted 29 January 2015

\section{DESCRIPTION}

A 38-year-old male driver was involved in a road traffic accident. He was brought to the emergency department after a high-speed frontal impact against a concrete wall. He could not remember what had led to the accident. He was treated according to the Acute Trauma Life Support (ATLS) guidelines. He was fully conscious, alert and orientated with a Glasgow Coma Scale score of $15 / 15$ with equal and reactive pupils. His blood sugar was normal. He was found to have minor orthopaedic injuries in the distal limbs.

Owing to the fact that the patient had transient amnesia that could not be explained, a brain CT was ordered, which showed an extensive lipoma of the corpus callosum (figures 1-4). This was interpreted as the cause of a possible epileptic fit that resulted in a transient loss of consciousness, which subsequently led to his accident. The patient was discharged home on anti-epileptics without surgery.

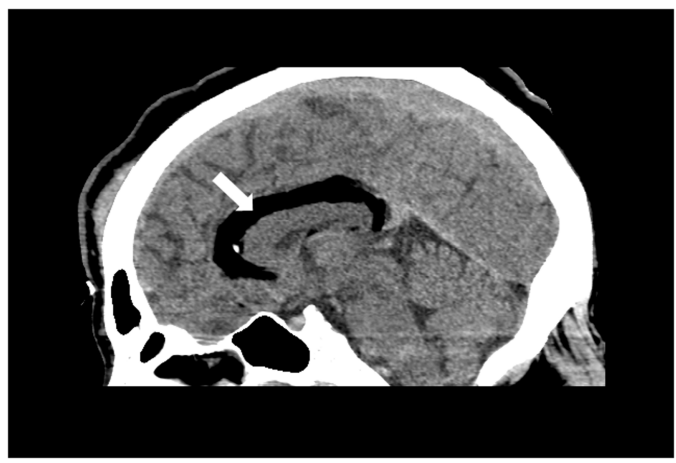

Figure 1 Brain CT-sagittal plane, white arrow shows a large, well-defined low-density lesion involving the genu and body of the corpus callosum.

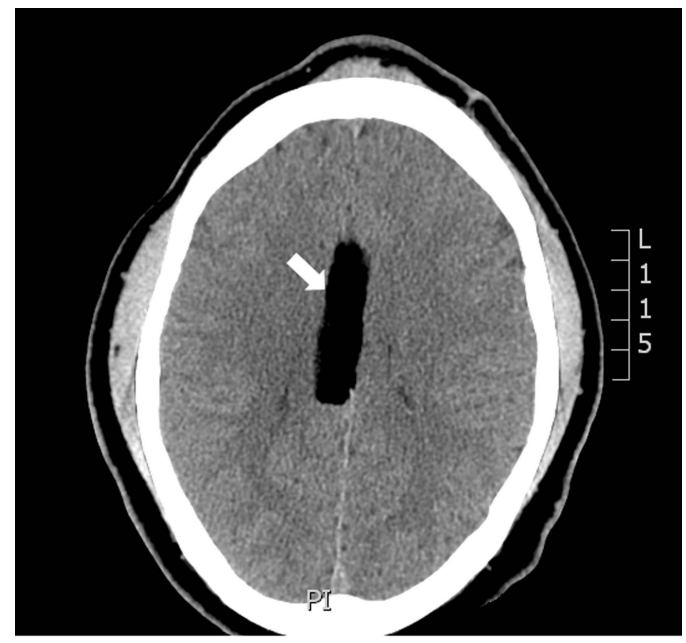

Figure 2 Brain CT-horizontal plane, white arrow shows a large, well-defined low-density lesion involving the genu and body of the corpus callosum.

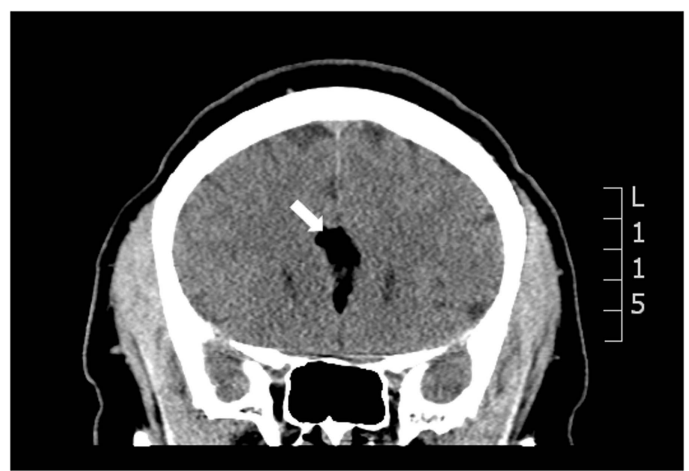

Figure 3 Brain CT-coronal plane, white arrow shows a large, well-defined low-density lesion involving the genu and body of the corpus callosum. 
Figure 4 Series of CT brain slicesincidental finding representing a lipoma of the corpus callosum.

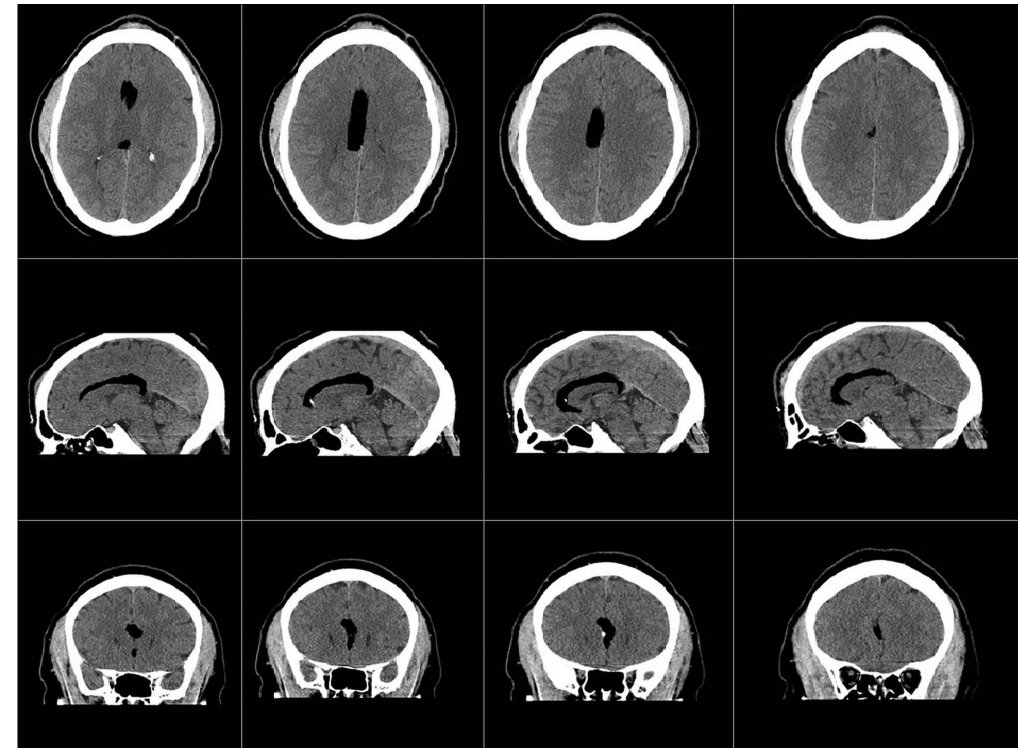

Acknowledgements The authors would like to thank Dr Laila Hussain for her help and support in editing the case and images.

Contributors SJ and TA diagnosed and managed the patient mentioned in the case. MA and SJ wrote the case manuscript and learning points, and performed the literature review. TA was the attending consultant when the patient presented to the emergency department. He reviewed the manuscript, made the necessary corrections to language and offered his suggestions.

\section{Competing interests None.}

Patient consent Obtained.

Provenance and peer review Not commissioned; externally peer reviewed. varying degrees of brain malformations. Associated anomalies include agenesis of surrounding tissues, frontal bone defects or facial dysplasia and cerebral vascular defects. ${ }^{1}$

- Intracranial lipomas may present with symptoms such as headache, seizures, local mass effect or may be diagnosed incidentally during evaluation following trauma. ${ }^{2}$

- CT imaging of lipomas shows the hypo attenuation characteristic of fat. MRI reveals a homogeneous T1 hyperintensity and $\mathrm{T} 2$ hypointensity/isointensity. ${ }^{2}$

- The prognosis of intracranial lipomas is generally good, especially for pure corpus callosum lesions. Surgical intervention is limited depending on the patient's symptoms, surgical feasibility and associated malformation. ${ }^{2}$

\section{REFERENCES}

Truwit CL, Barkovich AJ. Pathogenesis of intracranial lipoma: an MR study in 42 (1990;155:855-64. http://www.ajronline.org

Yilmaz N, Unal 0, Kiymaz N, et al. Intracranial lipomas-a clinical study. Clin Neuro Neurosurg 2006;108:363-8. http://www.sciencedirect.com

Copyright 2015 BMJ Publishing Group. All rights reserved. For permission to reuse any of this content visit http://group.bmi.com/group/rights-licensing/permissions.

BMJ Case Report Fellows may re-use this article for personal use and teaching without any further permission.

Become a Fellow of BMJ Case Reports today and you can:

- Submit as many cases as you like

- Enjoy fast sympathetic peer review and rapid publication of accepted articles

- Access all the published articles

- Re-use any of the published material for personal use and teaching without further permission

For information on Institutional Fellowships contact consortiasales@bmjgroup.com

Visit casereports.bmj.com for more articles like this and to become a Fellow 